\title{
The Unicorn exists! A remarkable new genus and species of Perilissini (Hymenoptera: Ichneumonidae) from South East Asia
}

\author{
Alexey RESHCHIKOV ${ }^{1,2)} \&$ Cornelis VAN ACHTERBERG ${ }^{3)}$ \\ ${ }^{1)}$ College of Ecology and Evolution, Sun Yat-sen University, 135 Xingangxi Street, Guangzhou, Guangdong 510275, China; e-mail: alexey.reshchi- \\ kov@gmail.com \\ 2) corresponding author \\ ${ }^{3)}$ Shaanxi Key Laboratory for Animal Conservation/Key Laboratory of Resource Biology and Biotechnology in Western China, Ministry of Educati- \\ on, College of Life Sciences, Northwest University, 229 North Taibai Av., Xi'an, Shaanxi 710069, China
}

\author{
Accepted: \\ $16^{\text {th }}$ November 2018 \\ Published online: \\ $23^{\text {rd }}$ November
}

\begin{abstract}
Gilen gen. nov. (type species G. orientalis sp. nov.) from South East Asia is described and illustrated. The new taxon has a produced mid-longitudinal facial projection, which differentiates it from all other known genera of Ichneumonidae. It belongs to the tribe Perilissini in the subfamily Ctenopelmatinae (Hymenoptera, Ichneumonidae) and is recorded from Laos, Northern Thailand and Vietnam.
\end{abstract}

Key words. Hymenoptera, Ichneumonidae, new genus, new species, parasitoid, facial projection, Laos, Thailand, Vietnam, Oriental Region

\section{Introduction}

The tribe Perilissini, along with eight other tribes, belongs to the subfamily Ctenopelmatinae, one of the most poorly known groups in the Ichneumonidae (GAULD 1997). The Ctenopelmatinae are well represented in all major zoogeographic regions, occurring from the Arctic to the tropics, and comprise 1523 species in 107 genera including 287 species and 24 genera of Perilissini (RESHCHIKOv 2011; Yu et al. 2016; KASPARYAN 2016, 2017; KASPARYAN et al. 2016; Lima \& KuMAgai 2016; ReshCHIKov 2016; ReshchiKov et al. 2017a,b,c, 2018). We did not count here the genera Bremiella Dalla Torre, 1901 and Scolomus Townes \& Townes, 1950 as Ctenopelmatinae (Gauld \& Wahl 2006, Araujo et al. 2018), neither the genus Labrossyta Förster, 1869 as Perilissini (Townes 1970). Being koinobiont endoparasitoids of sawfly larvae Ctenopelmatinae closely follow the distribution patterns of their hosts with the highest diversity in the north temperate zone and the tropical fauna that have developed on the basis of invasions from the Holarctic along mountain ranges (Malaise 1945, Reshchíov 2015). Thus 167 per- ilissine species are recorded from the Holarctic Region and only 35 species from the Oriental Region (Yu et al. 2016, ReshCHIKov et al. 2017a).

Here we describe a new genus and species of Perilissini from South East Asia based on recently collected specimens. Its morphology suggests that it is a member of the Perilissini where we tentatively place it.

\section{Material and methods}

This work is based on material collected during the TIGER project in Thailand (Queen Sirikit Botanic Garden, The Thai Forestry Group, The Hymenoptera Institute of the University of Kentucky, The Natural History Museum of Los Angeles County, http://sharkeylab.org/tiger/) in 2006-2009, by the second author in cooperation with Rob de Vries in Vietnam (the Naturalis Biodiversity Center, Netherlands) in 1999-2011 and specimens from Laos present in the Biologiezentrum Linz.

Type specimens are deposited at the following collections:

IEBR Institute of Ecology and Biological Resources, Hanoi, Vietnam; 
OLML Biologiezentrum Linz - Oberösterreichisches Landesmuseum, Linz, Austria;

QSBG Queen Sirikit Botanic Garden, Chiang Mai, Thailand;

RMNH Naturalis Biodiversity Center, Leiden, the Netherlands.

The morphological terminology follows GAULD (1991). Metasomal tergites are abbreviated as T. Images were taken with a Canon Digital Camera 40D, and combined with Zerene ${ }^{\circledR}$.

\section{Taxonomy}

Subfamily Ctenopelmatinae Förster, 1869

Tribe Perilissini Thomson, 1883

\section{Gilen gen. nov.}

Type species. Gilen orientalis sp. nov. by present designation.

Diagnosis. Gilen can be distinguished from other genera of Perilissini by the following combination of character states: produced mid-longitudinal facial projection (Figs 1A, 1B, 2A); lower mandibular tooth much longer than upper (Fig. 1B); occipital carina incomplete dorsally (Fig. 2B), and joined with hypostomal carina at base of mandible (Fig. 2D); occiput with distinct concavity (Fig. 2B); T1-3 with slight transverse impressions (Fig. 1E); last visible sternites in male with hind margins concave (Fig. 2E).

The strong mid-longitudinal facial projection of Gilen is a unique character in the Ichneumonidae. The occipital carina joined with hypostomal carina at base of mandible (Fig. 2D), hind wing with cu-a receiving $\mathrm{Cu} 1$ far below middle, and concave hind margins of last visible sternites in male (Fig. 2E) are characters shared with Lathrolestes Förster, 1869, Neurogenia Roman, 2010 and Priopoda Holmgren, 1856. It is therefore assumed that these genera are most likely closely related to Gilen.

Description. Fore wing length $6.8-7.0 \mathrm{~mm}$.

Head. Clypeus flat in lateral view (Figs 1A, 2A), its lower margin blunt and more or less bulging apically (Fig. 1B). Face (in anterior view) with goblet-shaped mid-longitudinal projection (Figs 1A, 1B, 2A), and rather sparsely setose (Fig. 1B). Anterior tentorial pit rather large (Fig. 1B). Eyes bare (Figs 1B, 2A). Lower mandibular tooth much longer than upper (Fig. 1B). Occipital carina incomplete dorsally (Fig. 2B), ventrally joined with hypostomal carina at base of mandible (Fig. 2D). Occiput with distinct concavity (Fig. 2B).

Mesosoma. Epomia absent (Fig. 2C). Notauli very shallow and indistinct (Fig. 2B). Mesopleuron with sternaulus-like impression (Fig. 2C). Epicnemial carina distant from anterior margin of mesopleuron (2C). Propodeum in lateral profile convexly rounded (Fig. 1A), with carinae complete except for area basalis, which is absent (fused with area superomedia) (Fig. 1C). Forewing with areolet petiolate (Fig. 1A). Pterostigma receiving vein $\mathrm{Rs}+2 \mathrm{r}$ at its basal 0.35 . Vein $2 \mathrm{~m}$-cu with a single bulla. Hind wing with cu-a receiving $\mathrm{Cu} 1$ well below middle. Tarsal claws strongly pectinate (Fig. 1D). Fore tibia with apical tooth.

Metasoma distinctly and densely punctate, sparsely setose. T1 as long as broad with dorsal longitudinal carina defined. Glymma deep. T1-3 with slight transverse impression. Ovipositor sheath flat, not longer than depth of metasomal apex. Ovipositor straight, with a long, shallow, subapical dorsal notch. Last visible sternites in male with hind margin concave (Fig. 2E). Parameres broad and short (Fig. 2E).

Differential diagnosis. See Key and Discussion below. Etymology. The generic name 'Gilen' refers to a mythical single horned creature (Thai name: กิเลน) known in Thai and other Asian cultures. It refers to the unique mid-longitudinal facial projection. The gender is masculine.

Species included. The genus is described as monotypic.

\section{Partial key to the genera of the tribe Perilissini}

This key enables identification of genera with hypostomal carina separated from occipital carina ventrally or joining occipital carina at base of mandible

1 Produced mid-longitudinal facial projection present (Figs 1A, 1B, 2A). T1-3 with slight transverse impression. ..................................... Gilen gen. nov.

- Face without mid-longitudinal projection. T1-3 without slight transverse impression........................ 2

2 Vein $\mathrm{M}+\mathrm{Cu}$ of fore wing with tubercle or spur. Male parameres usually very long and narrow.

Neurogenia Roman, 1910

- Vein $\mathrm{M}+\mathrm{Cu}$ of fore wing without tubercle or spur. Male parameres usually not narrow. ....................... 3

3 T1 in female approximately twice as long as broad. Apical margin of last visible sternite in male with one or several notches. Male parameres broadly triangular. Aedeagus reflexed and pointed apically, with adzelike blade.

Priopoda Holmgren, 1856

- T1 in female less than twice as long as broad. Apical margin of last visible sternite in male without notches. Male parameres mostly broadly rounded or rectangular in dorsal view. Aedeagus rounded and clubbed distally, without adze-like blade.

Lathrolestes Förster, 1869

\section{Gilen orientalis sp. nov. (Figs 1-2)}

Type material. HоLотYPE: $\odot$, 'THAILAND, Phitsanulok, Thung Salaeng Luang NP, Moist evergreen forest, $16^{\circ} 50.641^{\prime} \mathrm{N} 100^{\circ} 52.894^{\prime} \mathrm{E}, 557 \mathrm{~m}$., 25.viii.-1.ix.2006, Malaise trap, leg. Pongpitak Pranee, T572' (QSBG). Paratypes: LAOS: đa, Khammouane, Ban Khoun Ngeun, $18^{\circ} 07^{\prime} \mathrm{N}$ $104^{\circ} 29^{\prime}$ E, 250 m, 20.-29.v.2004, Jendek \& Šauša leg. (OLML); , THAILAND, Phitsanulok, Thung Salaeng Luang NP, Mix deciduous forest, $16^{\circ} 50.319^{\prime} \mathrm{N} 100^{\circ} 51.792^{\prime} \mathrm{E}, 479$ m., 11.-18.viii.2006, Malaise trap, Pongpitak Pranee leg., T568 (QSBG). THAILAND: + , Chiang Mai, Doi Chiangdao NP, Pha Tang substation, $19^{\circ} 24.978^{\prime} \mathrm{N} 98^{\circ} 54.886^{\prime} \mathrm{E}$, 526 m., 2.-9.xi.2007, Malaise trap, S. Jugsu \& A. Watwanich leg., T5701 (QSBG); 웅, Chiang Mai, Huai Nam Dang NP, Guest house, $19^{\circ} 18.803^{\prime} \mathrm{N}$ $98^{\circ} 36.395^{\prime} \mathrm{E}, 1589 \mathrm{~m}, 13 .-20$. ii.2008, Malaise trap, Anuchart \& Thawatchai leg., T5609 (QSBG). VIETNAM: 2 , Dak Lak, Chu Yang Sin NP, Krong K'Mar, 740-900 m., 2.-10.vi.2007, Malaise trap, C. v. Achterberg \& R. de Vries leg. (RMNH); 2 ô, Dong Nai, Cat Tien NP, eco-trail, 100 m, 13.-20.vi.2007, Malaise trap, C. v. Achterberg \& R. de Vries leg. (RMNH, IEBR).

Description. Female (holotype). Body matt and sparsely setose. Antenna slender, approximately 1.3 times as long as fore wing and with 42 flagellomeres. Scape almost as 


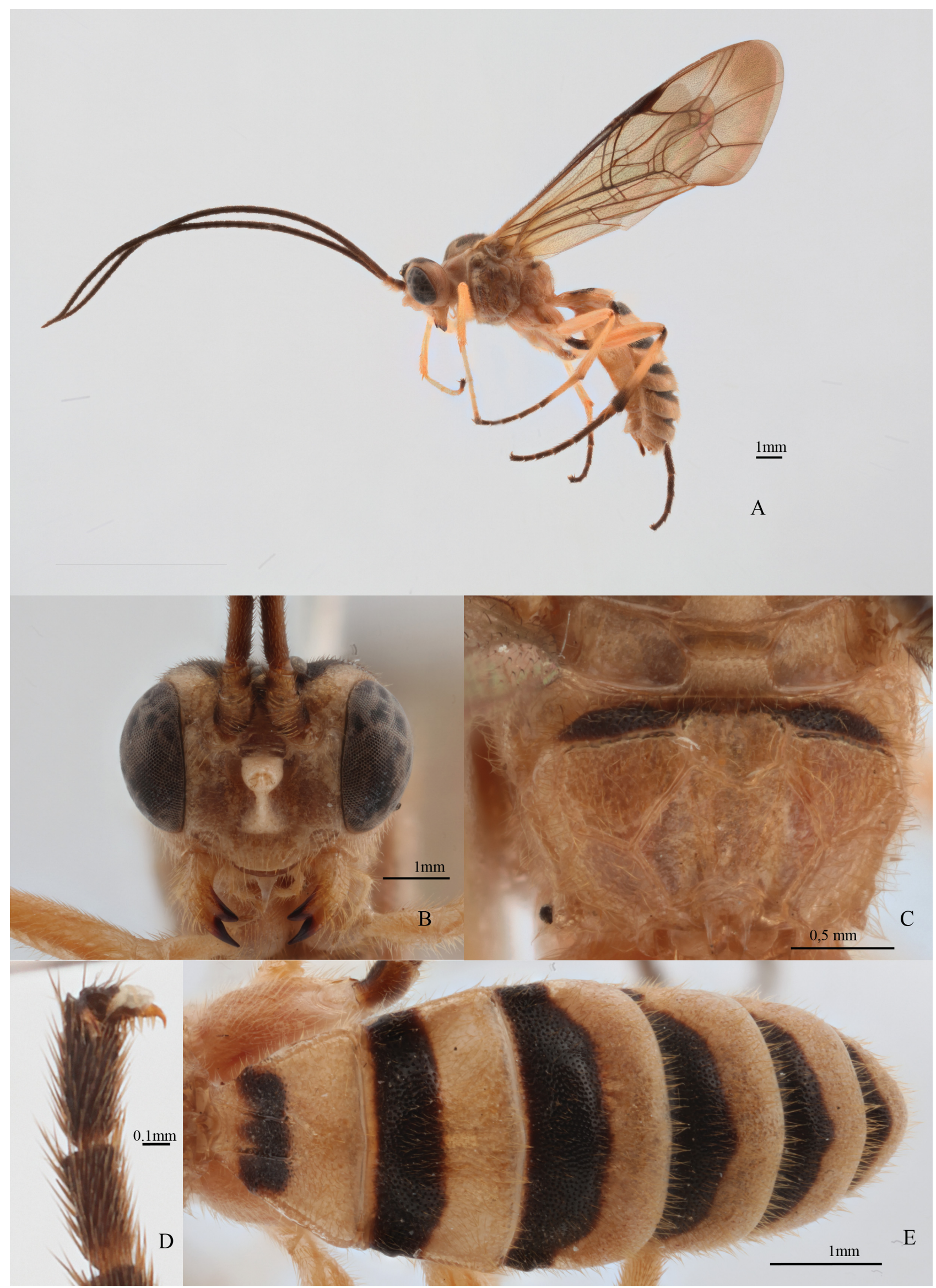

Fig. 1. Gilen orientalis sp. nov., holotype + . A - lateral habitus; $\mathrm{B}$ - face; $\mathrm{C}$ - propodeum; D - tarsal claw; $\mathrm{E}$ - metasomal tergites dorsally. 


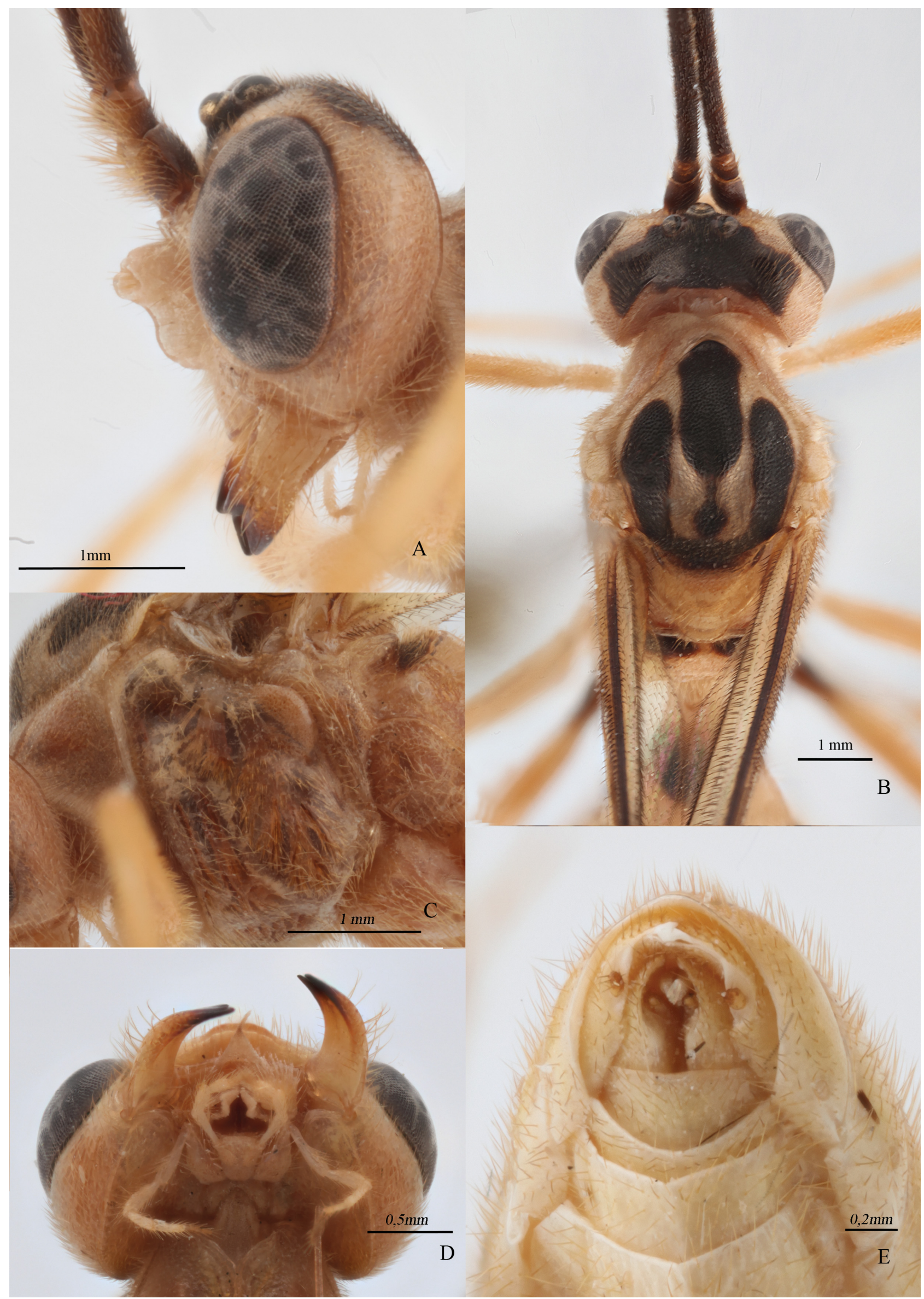

Fig. 2. Gilen orientalis sp. nov., holotype + (except E - paratype ${ }^{\top}$ ). A - head laterally; B - head and mesosoma dorsally; C - mesopleuron; D - head ventrally with occipital carina joined hypostomal carina at base of mandible; $\mathrm{E}-$ distal sternites of male. 
long as broad. Head narrowed behind eyes, matt, without punctures and shagreened. Lateral ocellus separated from eye margin by 1.6 times its widest diameter. Face with goblet-shaped (in anterior view) mid-longitudinal projection (Figs 1A, 1B, 2A). In its dorsal part it is joined by carina to antennal socket, the distal tip of this projection with a lateral impression. Clypeus 0.4 times as high as wide, not separated from face. Malar space 0.4 times basal mandible width.
Mesoscutum matt, finely punctate. Mesopleuron weakly shining, setose and sparsely punctate. Propodeal carina complete (Fig. 1C). Area basalis absent (fused with area superomedia). Area superomedia heptagonal. Spiracles weakly oval, 1.5 times as long as broad. Hind femur 4 times as long as broad. Hind tibia 7 times as long as apically broad. First tarsomere of hind leg 6.6 times as long as broad and 2.1 times as long as second tarsomere. Ovipositor sheath $0.2 \times$ as long as hind tibia.

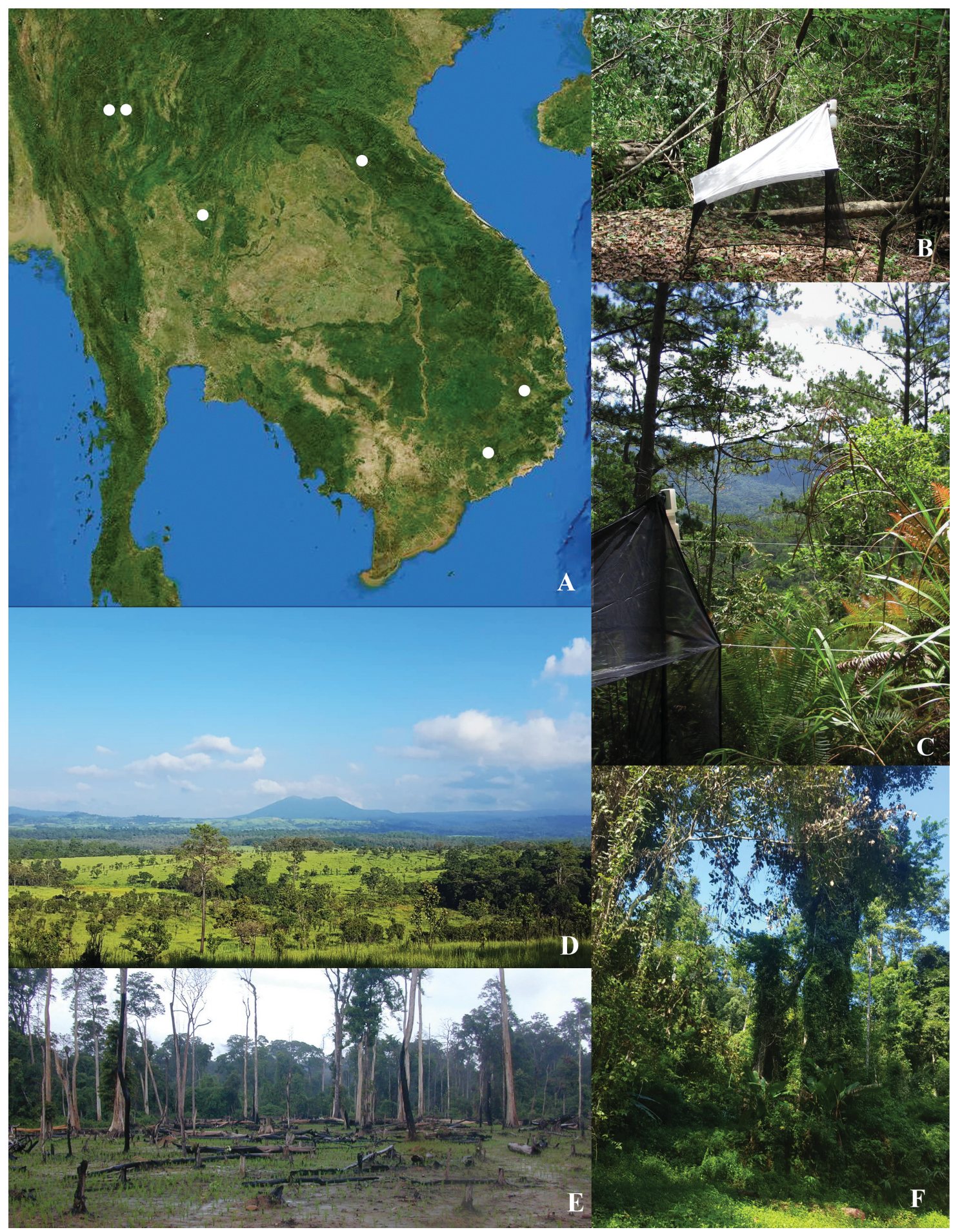

Fig. 3. Gilen orientalis sp. nov. distribution and habitats. A - distribution; B - Malaise trap and habitat in Cat Tien National Park, 100 m.a.s.l. (Dong Nai, Vietnam), C. v. Achterberg (); C - Malaise trap and habitat in Chu Yang Sin National Park, 740-900 m.a.s.1. (Dak Lak, Vietnam), C. v. Achterberg ( ); D -Thung Salaeng Luang National Park of the type locality (Phitsanulok, Thailand), A. Giudici $\mathbb{C}$; E -, Ban Khoun Ngeun (Khammouane, Laos) E. Jendek $\odot$; F - habitat in Doi Chiangdao National Park (Chiang Mai, Thailand), A. Giudici @. 
Colouration yellow, except for the following which are marked with black: antenna (dorsally), teeth of mandible, dorsal part of head, pterostigma, fifth tarsomere of fore leg, distal part of first tarsomere and second till fifth tarsomeres of middle leg, hind trochanter, proximal and distal edges of hind tibia and hind tarsus, most of mesonotum (Fig. 2B), basal part of propodeum, middle transverse stripe of $\mathrm{T} 1$ and anterior parts of further tergites, ovipositor sheath. Etymology. The specific name is the Latin adjective orientalis $(-i s,-e)$ (= eastern, oriental) and refers to species area of distribution.

Distribution. Oriental Region, recorded from Laos, Thailand and Vietnam (Fig. 3).

\section{Discussion}

The prominent feature of the Ctenopelmatinae is a small tooth-like process on the outer distal rim of the fore tibia, although similar structures are also found in a number of other subfamilies that are obviously not closely related, e.g. in Campopleginae. The subfamily is paraphyletic (QUICKE et al. 2009) and the phylogenetic analysis is badly needed, together with an evaluation of the limits of Perilissini.

Members of Perilissini can usually be recognized by the combination of tyloids on the first flagellomeres of antennae, pectinate tarsal claws, relatively large and posteriorly placed glymma. The following genera of Perilissini can be characterized by their hypostomal carina which is separated from the occipital carina ventrally or joins the occipital carina at the base of the mandible: Lathrolestes Förster, 1869, Priopoda Holmgren, 1856 and Neurogenia Roman, 1910. The newly discovered genus shares the last of the two character states.

Most Ctenopelmatinae are koinobiont endoparasitoids of sawflies (Symphyta), and not surprisingly most of the records are from Tenthredinidae, which is the largest family of sawflies (QUICKE 2015). Various groups specialised on species of the sawfly families Argidae (GAuld 1997), Cimbicidae (Sheng et al. 2004), Pamphiliidae (BArron 1981, Kasparyan 2004) and Pergidae (Wharton et al. 2008, 2010). In addition, several members of the subfamily are parasitoids of leaf mining sawfly larvae (PSCHORN-WALCHER \& AltenHOFER 1989).

Unfortunately, nothing is known about the biology of the newly described genus. But protrusions on the face or clypeus occur in several genera of Braconidae (VAN ACHTERBERG 1983, 1995; Butcher \& Quicke 2015), Pteromalidae (BouČEK 1988) and Platygastroidea (CALECA \& BIN 1995, MAsner et al. 2007). These braconid genera, belonging mainly to the subfamily Braconinae (Braconidae), are partly but not closely related (VAN ACHTERBERG 1983) and their biology is unknown except for one genus containing parasitoids of the beetle family Anthribidae. The faces of these wasps suggest they push their way through the host's microhabitats, i.e. stems, silk webbing, leaf-folds, ties or the soil (Quicke 2015). It is therefore possible that $G$. orientalis attacks the web concealed sawfly larvae of pamphiliids or stem borers of the subfamily Blennocampinae (Evenhuis 1973, Hinz 1996).
The new genus has an Oriental distribution covering Indochina with records from Central Laos, Northern Thailand and Southern Vietnam (Fig. 3A). All records are from low and middle elevations range from 100 till $900 \mathrm{~m}$ a.s.l. (except Huai Nam Dang National Park - 1589 m) (Figs 3B-E) and belong to deciduous, semi-deciduous forests and that cover a large area in mainland South-East Asia extending from northeastern India and Myanmar through Thailand to the Mekong River region of Laos and the lowlands of Cambodia and southern Vietnam (Rundel 1999).

\section{Acknowledgements}

The authors are grateful to Martin Schwarz (OLML), Michael Sharkey (University of Kentucky, Lexington, USA), Wichai Srisuka (QSBG), Frederique Bakker (RMNH) for assistance with collections access and providing material. We are also thankful to Tony Hunter (National Museums Liverpool, UK) and Petr Kment (National Museum, Prague, Czech Republic) for checking English and manuscript style, Matthias Riedel (Bavarian State Collection of Zoology, Munich, Germany) and Mao-Ling Sheng (General Station of Forest Pest Management, Shenyang, China) for their reviews and rather useful remarks, Antonio Giudici (Koh Phangan, Thailand) and Eduard Jendek (Czech University of Life Sciences, Prague, the Czech Republic) for provided photos of the habitats. The first author's visit to the RMNH was supported by a Martin Fellowship from the Naturalis Biodiversity Center (Leiden, the Netherlands). The second author thanks the Uyttenboogaart-Eliasen Stichting (Haarlem, the Netherlands) for financial support and the staff of the IEBR for their support during the fieldwork in Vietnam.

\section{References}

ARAUJO R. O., VIVALLO F. \& SANTOS B. F. 2018: Discovery of two new Andean species of Scolomus (Townes \& Townes), with a key to all known species (Hymenoptera: Ichneumonidae: Metopiinae). Zootaxa 4429(1): 189-194.

BARRON J. R. 1981: The Nearctic species of Ctenopelma (Hymenoptera, Ichneumonidae, Ctenopelmatinae). Naturaliste Canadien 108: 17-56.

BOUČEK Z. 1988: Australasian Chalcidoidea (Hymenoptera). C. A. B. International, Wallingford, $832 \mathrm{pp}$.

BUTCHER B. \& QUICKE D. 2015: A remarkable new genus and species of Rogadinae (Hymenoptera: Braconidae) of uncertain tribal placement, from Papua New Guinea, resembling Betylobraconini stat. nov. Journal of Natural History 49: 2045-2054.

CALECA V. \& BIN F. 1995: World revision of the genus Encyrtoscelio Dodd (Hymenoptera: Scelionidae). Invertebrate Taxonomy 9: 1021-1045.

EVENHUIS H. H. 1973: Investigations on the rose tip-infesting sawfly Ardis brunniventris (Hymenoptera, Tenthredinidae). Mededelingen van de Faculteit Landbouwwetenschappen Rijksuniversiteit Gent 38: $1127-1131$

GAULD I. D. 1991: The Ichneumonidae of Costa Rica, 1. Memoirs of the American Entomological Institute 47: 1-589.

GAULD I. D. 1997: Subfamily Ctenopelmatinae. Pp. 177-262. In: Ichneumonidae of Costa Rica, 2. Memoirs of the American Entomological Institute 57: 1-485.

GAULD I. D., GODOY C., UGALDE J. \& SITHOLE R. 2002: The Ichneumonidae of Costa Rica, 4. Memoirs of the American Entomological Institute 66: 1-768. 
HINZ R. 1996: Zur Systematik einiger Ctenopelmatinae (Hymenoptera, Ichneumonidae). Nachrichtenblatt der Bayerischen Entomologen 45: 75-78.

KASPARYAN D. R. 2004: A review of Palaearctic species of the tribe Ctenopelmatini (Hymenoptera, Ichneumonidae). The genera Ctenopelma Holmgren and Homaspis Foerster. Entomologicheskoe Obozrenie 83: 4-13 (In Russian, English summary). [English translation published in Entomological Review, 2004, 84: 332-357.]

KASPARYAN D. R. 2016: A new species of the genus Rhorus Förster, 1869 (Hymenoptera: Ichneumonidae: Ctenopelmatinae) from Mongolia. Euroasian Entomological Journal 15(1): 62-65 (in Russian, English summary).

KASPARYAN D. R. 2015: Review of the Western Palaearctic Ichneumon-flies of the genus Rhorus Förster, 1869 (Hymenoptera, Ichneumonidae: Ctenopelmatinae). Part IV. The species with the reddish metasoma and black face (Addendum). Entomological Review, 2017, 97(1): 116-131.

KASPARYAN D. R., CHOI J. K. \& LEE J. W. 2016: New species of Rhorus Förster, 1869 (Hymenoptera: Ichneumonidae: Ctenopelmatinae) from South Korea. Zootaxa 4158(4): 569-576.

LIMA A. R. \& KUMAGAI A. F. 2016: Lathrolestes Förster, 1869 (Hymenoptera, Ichneumonidae) from Brazil, with description of two new species and a key to the Neotropical species. Zootaxa 4170(3): 587-593.

MASNER L., JOHNSON N. F. \& ARIAS-PENNA T. M. 2007: Tyrannoscelio, a new genus of Neotropical Scelionidae (Hymenoptera, Platygastroidea) with description of two new species. American Museum Novitates 3551: 1-8.

PSCHORN-WALCHER H. \& ALTENHOFER E. 1989: The parasitoid community of leaf-mining sawflies Fenusini and Heterarthrini, a comparative analysis. Zoologische Annalen 222: 37-56.

QUICKE D. L. J. 2015: The Braconid and Ichneumonid Parasitoid Wasps: Biology, systematics, evolution and ecology. John Wiley \& Sons, Chichester, $752 \mathrm{pp}$.

QUICKE D. L. J., LAURENNE N. M., FITTON M. G. \& BROAD G. R. 2009: A thousand and one wasps: a 28S rDNA and morphological phylogeny of the Ichneumonidae (Insecta: Hymenoptera) with an investigation into alignment parameter space and elision. Journal of Natural History 43: 1305-1421.

RESHCHIKOV A. V. 2011: Emtgolia interrupta, a new Mongolian genus and species of tribe Perilissini (Hymenoptera: Ichneumonidae). Zoosystematica Rossica 19: 343-346.
RESHCHIKOV A. V. 2015: The world fauna of the genus Lathrolestes (Hymenoptera, Ichneumonidae). University of Tartu Press, Tartu, $247 \mathrm{pp}$.

RESHCHIKOV A. V. 2016: A new species of the genus Asthenara Förster, 1869 (Hymenoptera, Ichneumonidae) from Mexico with identification key. Zootaxa 4154(2): 190-192.

RESHCHIKOV A. V., CHOI J. K. \& LEE J. W. 2017a: Four new species of the genus Lathrolestes Förster, 1869 from South Korea (Hymenoptera, Ichneumonidae, Ctenopelmatinae). ZooKeys 657: 81-92.

RESHCHIKOV A. V., CHOI J. K., XU Z. F. \& PANG H. 2017b: Two new species of the genus Rhorus Förster, 1869 from Thailand (Hymenoptera, Ichneumonidae). Journal of Hymenoptera Research 54: 79-92.

RESHCHIKOV A. V., SÄÄKSJÄRVI I. E. \& POLLET M. 2018: Review of the New World genus Nanium Townes, 1967 (Hymenoptera: Ichneumonidae: Ctenopelmatinae), with two new species from the Neotropical region. European Journal of Taxonomy 459: 1-18.

RESHCHIKOV A. V., XU Z. F. \& PANG H. 2017c: First record of the genus Lethades Davis, 1897 from the Oriental region, with description of a new species (Hymenoptera, Ichneumonidae, Ctenopelmatinae). ZooKeys 644: 43-50.

RUNDEL P. W. 1999: Conservation priorities in Indochina - WWF Desk Study. Forest habitats and flora in Lao PDR, Cambodia, and Vietnam. World Wide Fund for Nature, Indochina Programme Office, Hanoi, 194 pp.

SHENG M. L., WU X. Y. \& LUO Y. G. 2004: [On the ichneumonids parasitizing Agenocimbex elmina (Hymenoptera) in Gansu, China.] Acta Zootaxonomica Sinica 29: 549-552 (in Chinese, English summary).

VAN ACHTERBERG C. 1983: Six new genera of Braconinae from the Afrotropical Region (Hymenoptera, Braconidae). Tijdschrift voor Entomologie 126: 175-202.

VAN ACHTERBERG C. 1995: Generic revision of the subfamily Bethylobraconinae (Hymenoptera: Braconidae) and other groups with modified fore tarsus. Zoologische Verhandelingen (Leiden) 298: 1-242.

WHARTON R. A., CAMMACK J. A. \& MULLINS P. L. 2010: A revision of westwoodiine genus Pergaphaga (Hymenoptera, Ichneumonidae, Ctenopelmatinae). ZooKeys 37: 35-68.

WHARTON R. A., ROEDER K. \& YODER M. J. 2008: A monograph of the genus Westwoodia (Hymenoptera: Ichneumonidae). Zootaxa 1855: $1-40$.

YU D. S., VAN ACHTERBERG K. \& HORSTMANN K. 2016: World Ichneumonoidea 2015. Taxonomy, biology, morphology and distribution. [Flash drive]. Taxapad®, Vancouver, Canada. 
